\title{
Determinants of Budgetary Slacks in State Owned Enterprises: Evidence from Indonesia
}

\author{
Dwi Indah LESTARI ${ }^{\star *}$, Patria Prasetio ADI
}

1,2Universitas Jenderal Achmad Yani, Cimahi, Indonesia

Email: dwiindah@ak.unjani.ac.id¹ , patriaprasetyo@ak.unjani.ac.id²

* Corresponding Author

\author{
Received: 12.05.2021 Accepted: 10.08.2021 Published: 03.10.2021 DOI: $10.47750 /$ QAS/22.184.10
}

\begin{abstract}
This study aims to examine the determinants of budgetary slacks, with a focus on informal system management from gender perspectives. The purposive sampling method was used to obtain data from all managers in Indonesian government enterprises by distributing questionnaire with a response rate of $75.3 \%$. Furthermore, the collected data were analyzed using SmartPLS program. The result showed that only organizational commitment has an impact on budgetary slack.
\end{abstract}

Keywords: Budget slack; gender; informal management control system; Indonesia government enterprises.

\section{Introduction}

Budget is one of the management control systems used to ensure all strategic plans are running properly (Anthony and Govindarajan, 2006). Most organizations use a budget as a control tool, however, not all utilize it effectively. In most cases, the manager is less committed to achieving the target set on a budget, thereby leading to the occurrence of slack.

The first research related to slack was carried out in 1953 by Aygris (Bakar and Amiruddin, 2014). However, till date, the slack budget research is still being debated in many literatures (Church, Hannan, and Jason, 2012; Bakar and Amiruddin, 2014). Moreover, research related to slack is unable to provide answers related to measures capable of preventing its occurrence in the budget (Gilabert, Gago, and Naranjo-gil, 2012).

To prevent slack, a manager can take advantage of formal and informal management control systems. However, in most research, more focus is placed on the formal management control system than the informal (Gilabert, Gago, and Naranjogil, 2012). This is because the informal management control system's effectiveness is yet to be proven (Chong and Ferdiansah, 2014; Gago-Rodríguez and Naranjo-Gil, 2016).

In most Asian and African countries, such as Indonesia, where culture put a significant role in a society, it is important to consider the informal management control system to help the organization reach its goal. Another interesting characteristic in Indonesia is the implication of manager role and slack from gender perspectives. Furthermore, research on gender perspectives is carried out in the budget topic because it enables the interactions between female and male managers with their team (Suhartini, Riadi, and Sari, 2015). According to Yuhertiana (2011), female and male managers have different characteristics and ways of thinking. Research carried out by Yuhertiana (2011) shows that female managers are more ethical in preparing budgets than their male counterparts.
Research related to gender is relatively rare, especially in Indonesia Yuhertiana (, 2011). Therefore, this study is proposed to fill the research gap and at the same time emphasize the importance of the informal management system and gender role in reducing slack.

Furthermore, this research focuses on informal management control systems in the form of organizational commitment, leadership style, cultural and personnel controls with gender perspectives.

\section{Literature Review}

\section{Agency Theory}

The agency theory developed by Meckling and Jensen (1976) stated that agents do not always act in the principal's best interest. Most times, agents react based on their interest and assumption that their capability is higher (Ekanayake, 2004). According to the agency theory, the principal has the ability to control agents and their cost through sufficient incentive. Many factors are associated with agency problems, such as asymmetric information (Muda, Limanto, and Erlina, 2020) an agent's personnel interest (Suhartini, Riadi, and Sari, 2015). These two factors trigger a loophole for the agent to participate in budget slack (Harvey, 2015).

\section{Contingency Theory}

In 1973, Luthans developed the Contingency Theory, which stated that no design fits all situations. Meanwhile, the classical approach believes that bureaucracy design leads to efficiency irrespective of the applied conditions.

According to Belkaoui (1989), there is no particular accounting system or strategy applicable to all types of companies. Therefore, no one management control system fits 
all type of companies.

Both informal and formal management control systems need to be chosen based on each company's condition. However, budget, as one of the control tools, often failed to carry out its function. Therefore, companies need both informal and formal management control systems to optimize the use of budgets.

\section{Budgetary Slack}

According to Anthony and Govindarajan (2006), budgetary slack is the difference between the budget number posed by a unit and the management's best guess.

Subordinates tend to pose the budget number that lowering the income target and raises the expense. Meanwhile, management tends to push their subordinate to reach higher income and press their expense to obtain their profit target. This asynchronous activity trigger's budgetary slack.

In general, companies apply a formal control management system to reduce slack. Things such as incentives and monitoring devices are often carried out to combat this activity. However, research carried out by Bakar and Amiruddin (2014) stated that the formal management control system is not good enough, therefore, management needs to consider an informal management control system.

Preliminary studies have shown that some informal factors affect budgetary slack, such as trust (Gilabert, Gago and Naranjo-gil, 2012; Delemark and Listherby, 2013; Bakar and Amiruddin, 2014; Chong and Ferdiansah, 2014; GagoRodríguez and Naranjo-Gil, 2016), culture (Ueno and Sekaran, 1992; Ueno and Wu, 1993; Delemark and Listherby, 2013; Bakar and Amiruddin, 2014; Suhartini, Riadi and Sari, 2015; Ashmeade, Mccambridge and Sullivan, 2017; Lestari, 2020), work pressure (Kahar, Rohman and Chariri, 2016), information system quality (Yang, Wang and Cheng, 2009), honesty (Blay, Douthit and Fulmer, 2019), gender (Suhartini, Riadi and Sari, 2015; Johansson and Wennblom, 2017), leadership style (Islami and Nahartyo, 2019), individual personnel values (Putra, Albab and Swara, 2019) and organizational commitment (Amran and Auzair, 2013; Baerdemaeker and Bruggeman, 2015).

\section{Organizational Commitment}

There are multiple definitions of commitment, which varied by differences in perspectives between one author and another (Klein, 2012). In this research, organizational commitment is seen as "a process of identifying and dedicating one's energies to the organization's goals and values" (Reichers, 1985).

Management tends to act based on their interest, and this is in accordance with the agency theory. However, by having a strong organizational commitment, it tends to lower the agency cost.

According to Baerdemaeker and Bruggeman (2015), management with strong commitment tends to act based on companies' interests, while those that are not committed tend to choose the option that benefits them more.

Research carried out by Nouri and Parker (1996) stated that organizational commitment affects budget slack. Management with strong commitment understands that budget slack tends to affect the company's performance and interest. Therefore, the
First hypothesis alternative is developed as follow:

Ha1: Organizational commitment has a negative impact on budgetary slack.

\section{Leadership Style (Gender Perspectives)}

Kleine and Weißenberger (2014) stated that the leadership style is a key factor in supporting the development of subordinates' organizational commitment.

Leadership is also a complex and multifaceted phenomenon that is examined with a wide variety of tools (Yukl, 1989). According to Kyj and Parker (2008), one of the most commonly used tools used to analyze it is leadership style.

Anthony and Govindarajan (2006) stated that the behaviour of subordinates' reflects on their leaders' behaviour. In the meantime the behaviour between males and females is different (Suhartini, Sari, and Riadi, 2019). However the term gender does not focus on the biological difference between male and female, rather it is the different role between them, which affects their behaviour from gender's perspectives.

Johansson and Wennblom (2017) stated that male employees put more trust in female supervisors. Trust lowers the tension to carry out budget slack (Gilabert, Gago, and Naranjo-gil, 2012; Bakar and Amiruddin, 2014; Chong and Ferdiansah, 2014). Within this framework, the second hypothesis alternative is developed as follow:

Ha2: The leadership style moderated by gender has negatives impact on budgetary slack.

\section{Cultural Control}

According to Kleine and Weißenberger (2014), cultural control is part of the informal management system. It reflects on the socialization process and intends to make sure that everyone in that company understands the value and assumption applied in a company.

Therefore, when the value is understood and implemented, it lowers management's tendency to conduct slack. The third hypothesis alternative is developed as follow:

Ha3: Cultural control has a negative impact on budgetary slack.

\section{Personnel Control}

Personnel control is also part of the informal management system. It comprises employee's related activity in carrying out a daily operation, such as training and recruitment process.

As an informal management control system, this element is applied differently from one company to another. It takes account of contingency theory that no one management control system fits all types of companies. Therefore, it is concluded that personnel control lower management tendency to carry out slack. Using this thinking framework, the fourth hypothesis alternative is developed as follow:

Ha4: Personnel control has negative impact on budgetary slack.

\section{Research Model}

Based on the literature, the conceptual framework is developed as follow: 


\section{GENERAL MANAGEMENT}

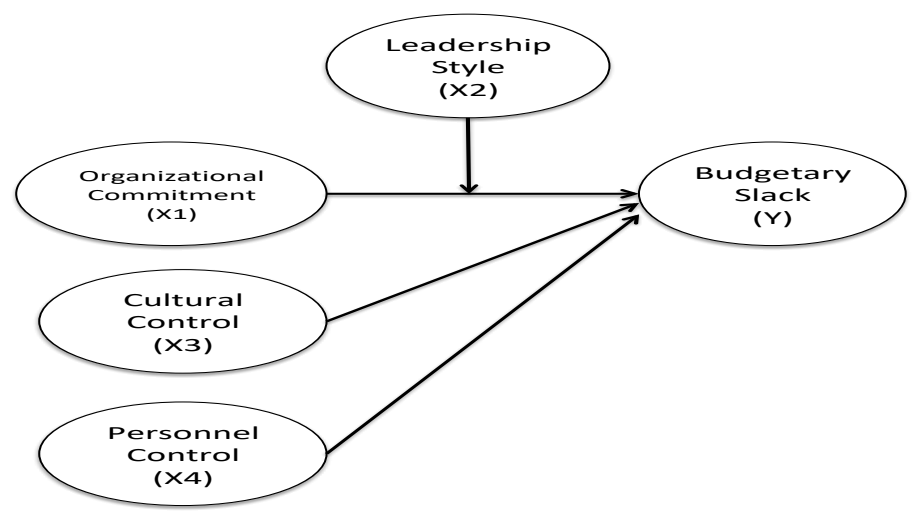

Figure 1: Research Model

\section{RESEARCH METHODS}

This study uses primary data with a quantitative approach. The sample population consists of all managers in the Stateowned government companies in Indonesia. Furthermore, the purposive sampling method was used to determine the sample, with criteria as follows:

- The managers need to be in the middle up

Out of 150 questionnaires distributed, 113 data at a response rate of $75.3 \%$, was collected. The questionnaire results were analyzed using the SmartPLS program. management level.

- The managers need to consider the budget in making a decision.

- $\quad$ Since the majority of State-owned government companies in Indonesia are located in Jakarta and Bandung, the sample population was selected from managers in these areas.

\section{Measurement}

The total instrument consists of 21 items measured on the Likert Scale from 1 (strongly disagree) to 7 (strongly agree).

The measurement used to carry out this research is shown in Table 1.

\begin{tabular}{|c|c|c|}
\hline Variable & Indicator & Reference \\
\hline \multirow{4}{*}{ Budgetary Slack (BS) } & $\begin{array}{l}\text { Standards set in the budget (BS } \\
\text { 1) }\end{array}$ & \multirow[t]{4}{*}{ (Dunk, 1993) } \\
\hline & Budget set (BS 2) & \\
\hline & Cost monitoring (BS 3) & \\
\hline & Budgetary target (B4, B5) & \\
\hline \multirow{5}{*}{ Organizational Commitment (OC) } & Employee's commitment (OC 1) & \multirow{5}{*}{$\begin{array}{l}\text { (Kleine and } \\
\text { Weißenberger, 2014) }\end{array}$} \\
\hline & Employee's loyalty (OC 2) & \\
\hline & Goal congruence (OC 3) & \\
\hline & Organization goal (OC 4) & \\
\hline & Company's image (OC 5) & \\
\hline \multirow{2}{*}{ Leadership Style (LS) } & $\begin{array}{l}\text { Supervisor's behaviour (LS 1, } \\
\text { LS 2, LS 3) }\end{array}$ & \multirow[t]{2}{*}{ (Kyj and Parker, 2008) } \\
\hline & $\begin{array}{l}\text { Supervisor's explanation (LS 4, } \\
\text { LS 5) }\end{array}$ & \\
\hline \multirow{2}{*}{ Gender } & Male & \multirow{2}{*}{$\begin{array}{l}\text { (Suhartini, } \\
\text { Sari, 2015) }\end{array}$} \\
\hline & Female & \\
\hline \multirow{4}{*}{ Cultural Control (CC) } & $\begin{array}{lll}\text { Sharing informal Code of } \\
\text { conducts (CC 1) }\end{array}$ & \multirow[t]{4}{*}{$\begin{array}{l}\text { (Kleine and } \\
\text { Weißenberger, 2014) }\end{array}$} \\
\hline & Mission statement (CC 2, CC 5) & \\
\hline & $\begin{array}{l}\text { Communication between top } \\
\text { management and employee } \\
\text { (CC 3) }\end{array}$ & \\
\hline & Organization core value (CC 4) & \\
\hline \multirow[b]{2}{*}{ Personnel Control (PC) } & $\begin{array}{l}\text { Employees' selection process } \\
\text { (PC 1, PC 2, PC 3) }\end{array}$ & \multirow[t]{2}{*}{$\begin{array}{l}\text { (Kleine and } \\
\text { Weißenberger, 2014) }\end{array}$} \\
\hline & $\begin{array}{l}\text { Training, development and } \\
\text { opportunity for employees (PC } \\
4, \text { PC 5) }\end{array}$ & \\
\hline
\end{tabular}

Table 1: Construct and Measurement 


\section{GENERAL MANAGEMENT}

\section{RESULTS}

The statistic result showed that the $\mathrm{R}$-square was 0,135 . It means that the model has the ability to analyze all variables by $13.5 \%$. Therefore, research related to informal management system needs to be carried out more extensively.

\section{Convergent validity on the outer model}

Convergent validity refers to the validity of items that reflects the indicator (Muafi et al., 2017). The composite reliability value is used to check convergent validity.

According to Hair et al. (2018), the reliability value between 0.7-0.95 shows that all latent variables can be used to predict structural functions on the inner model. Therefore, from table 2 below, it is concluded that there is no measurement error on the outer model.

\begin{tabular}{|l|l|l|}
\hline & $\begin{array}{l}\text { Composite } \\
\text { Reliability }\end{array}$ & Information \\
\hline Budgetary Slack & 0,886 & Reliable \\
\hline $\begin{array}{l}\text { Organizational } \\
\text { Commitment }\end{array}$ & 0,870 & Reliable \\
\hline Leadership Style & 0,890 & Reliable \\
\hline Cultural Control & 0,915 & Reliable \\
\hline Personnel Control & 0,880 & Reliable \\
\hline
\end{tabular}

Table 2: Composite Reliability

\section{Indicator loadings}

Indicator loadings were used to confirm the reliability of the tool. Although Hair et al. (2018) stated that the factor loading is above 0.708, Ghozali (2014) reported that each indicator's loading factor needs to be more than 0.5 . In this study, 7 indicators need to be eliminated from the model because it has factor loading less than 0.5 , namely OC 4 , LS 3 , LS 5 , CC 4 , BS 1, BS 3, and BS 6.

The path diagram is shown in figure 2 .

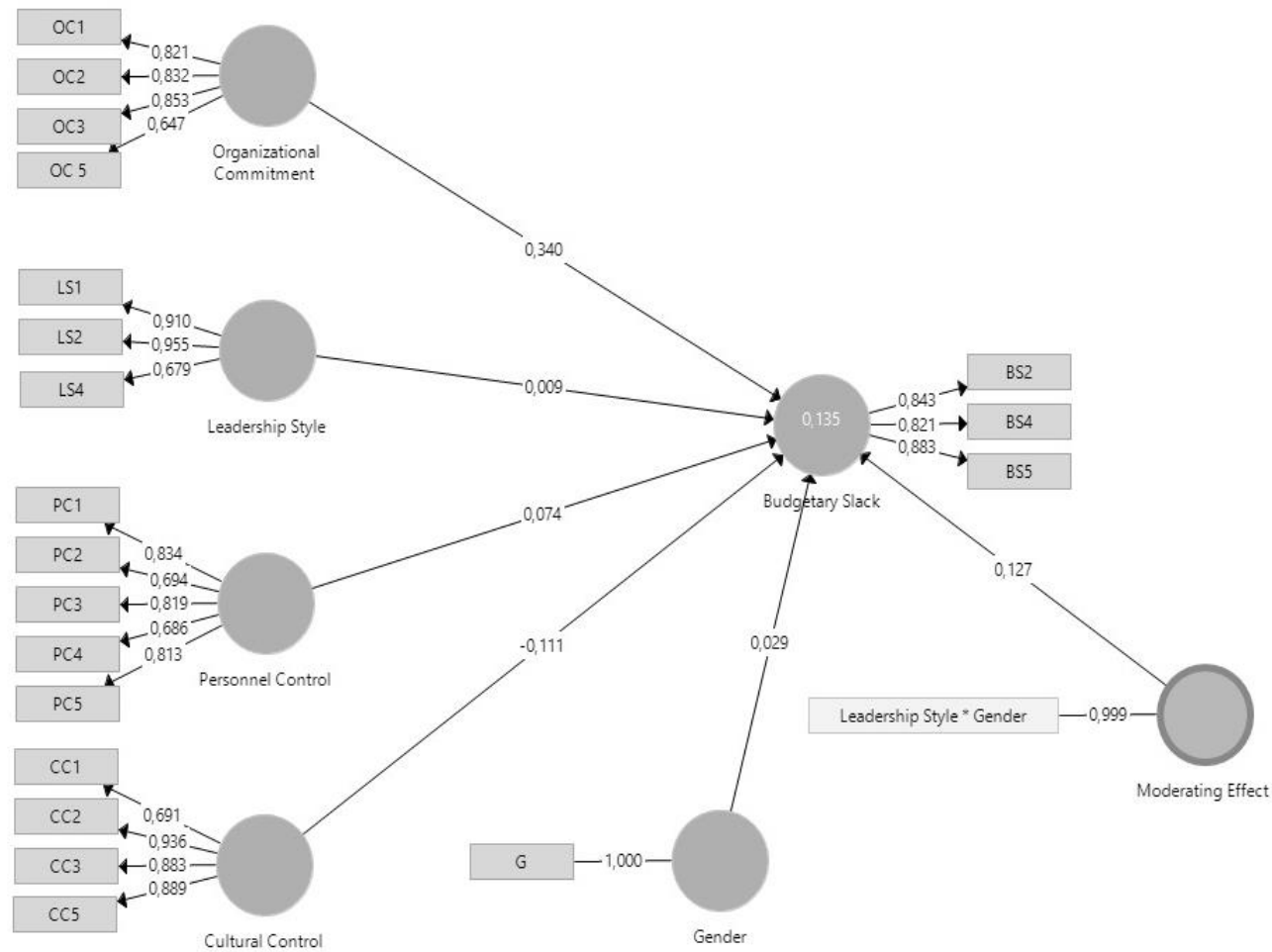

Figure 2: Path Diagram

\section{Discriminant validity on the outer model}

This test is used to ensure that each construct is empirically distinct from others in the model (Hair et al., 2019).
Table 3 below shows that all variables in this study are valid because the AVE square value is bigger than the correlation value 


\section{GENERAL MANAGEMENT}

\begin{tabular}{l|c|c|c|c|c|} 
& $\boldsymbol{B S}$ & $\boldsymbol{C C}$ & $\boldsymbol{L S}$ & $\boldsymbol{O C}$ & $\boldsymbol{P C}$ \\
\hline BS2 & 0,843 & 0,040 & 0,061 & 0,218 & 0,086 \\
\hline BS4 & 0,821 & 0,179 & 0,180 & 0,240 & 0,150 \\
\hline BS5 & 0,883 & 0,129 & 0,213 & 0,355 & 0,243 \\
\hline CC1 & 0,072 & 0,691 & 0,272 & 0,322 & 0,661 \\
\hline CC2 & 0,152 & 0,936 & 0,350 & 0,584 & 0,702 \\
\hline CC3 & 0,105 & 0,883 & 0,308 & 0,498 & 0,679 \\
\hline CC5 & 0,124 & 0,889 & 0,323 & 0,502 & 0,678 \\
\hline LS1 & 0,142 & 0,226 & 0,910 & 0,414 & 0,416 \\
\hline LS2 & 0,220 & 0,306 & 0,955 & 0,482 & 0,425 \\
\hline LS4 & 0,068 & 0,619 & 0,679 & 0,466 & 0,648 \\
\hline OC 5 & 0,128 & 0,581 & 0,393 & 0,647 & 0,678 \\
\hline OC1 & 0,269 & 0,347 & 0,464 & 0,821 & 0,466 \\
\hline OC2 & 0,165 & 0,439 & 0,380 & 0,832 & 0,485 \\
\hline OC3 & 0,371 & 0,523 & 0,400 & 0,853 & 0,509 \\
\hline PC1 & 0,216 & 0,640 & 0,452 & 0,629 & 0,834 \\
\hline PC2 & 0,046 & 0,543 & 0,424 & 0,484 & 0,694 \\
\hline PC3 & 0,154 & 0,646 & 0,463 & 0,417 & 0,819 \\
\hline PC4 & 0,072 & 0,505 & 0,356 & 0,439 & 0,686 \\
\hline PC5 & 0,174 & 0,665 & 0,321 & 0,471 & 0,813 \\
\hline
\end{tabular}

Table 3: Cross Loading Measurement Result

\section{Inner Model test}

This study used the bootstrapping menu to generate T-
Statistic values that can be used to test the hypothesis at a significance level of $5 \%(T>1.97)$.

\begin{tabular}{|l|l|l|l|l|}
\hline & $\begin{array}{l}\text { Original } \\
\text { Sample }\end{array}$ & $\begin{array}{l}\text { Sample } \\
\text { Mean }\end{array}$ & $\begin{array}{l}\text { Standard } \\
\text { Deviation }\end{array}$ & T Stat \\
\hline OC $>$ BS & 0,340 & 0,324 & 0,131 & 2,597 \\
\hline LS $>$ BS & 0,009 & 0,003 & 0,120 & 0,071 \\
\hline CC $->$ BS & $-0,111$ & $-0,079$ & 0,149 & 0,746 \\
\hline PC $>$ BS & 0,074 & 0,091 & 0,172 & 0,432 \\
\hline Gender $->$ BS & 0,029 & 0,032 & 0,100 & 0,292 \\
\hline $\begin{array}{l}\text { Moderating } \\
\text { Effect }>\text { BS }\end{array}$ & 0,127 & 0,105 & 0,090 & 1,403 \\
\hline
\end{tabular}

Table 4: Path Coefficient Variables

Table 4 shows that only organizational commitment has an impact on budgetary slack.

\section{DISCUSSION}

\section{The relationship between commitment and budgetary slack}

The statistic result shows that organizational commitment positively impacts budgetary slack with a T-statistic value of 2.597 .

As earlier stated in the literature review, organizational commitment is an identification process used by a company to achieve its goal. According to the theory and previous research, organizational commitment has negatives result in budget slack. However, in Indonesian government enterprises, companies carry out special missions even though it is not listed in their budget or able to produce an adequate profit. This means that sometimes management is a force to create slack to fulfill the company's goal.

\section{The relationship between Leadership Style (gender perspectives) and budgetary slack}

The statistic result showed that leadership style has no significant impact on budgetary slack with a T-statistic value of 0.071 .

The result implies that there is no difference between male and female leadership styles in creating budget slack. This occurs because, according to liberal feminism theory, males and females act similarly in carrying out their job (Wibowo, 2011). Furthermore, Zuhdi (2019) stated that the difference between male and female leadership style occur due to social factors. Society assumes that they have different behaviour in working environment. However, the study conducted by Zuhdi (2019) reveals that more female presently work professionally.

Structure and consideration leadership style impact motivation and organizational performance, not on budgetary slack. The subject of this research is Indonesian government enterprises with similar procedures and rules. It creates a condition where leadership style cannot affect slack. For example Indonesian government enterprises minister decree no: KEP-101/MBU/2002 on Working Plan and Budget. The decree explains how Indonesian government enterprises get 
some capital portion from the government, and these companies also have to carry out specific regulations. In this matter, the management needs to adjust their leadership style with rules applicable to Indonesian government enterprises.

Therefore, it can be concluded that there is no difference between males and females in creating budgetary slack.

\section{The relationship between cultural control and budgetary slack}

The statistic result shows that cultural control has no significant impact on budgetary slack, with a T-statistic value of 0.746 .

According to Ismanto et al. (2020), culture consists of attitudes, experience, beliefs, and values. Meanwhile, cultural control comprises unwritten rules and policies. Therefore, top management needs to communicate with all employees to ensure everyone is understood (Kleine and Weißenberger, 2014).

The organization culture between one company and others is different. However, in general culture in Indonesian government enterprises are more strict compare to private companies. This happens due to specific rules that need to be applied by the government. Therefore, management tends to obey written rules compared to unwritten policies. This means that with or without cultural control, the tendency to carry out budget slack is not influenced.

\section{The relationship between personnel control and budgetary slack}

The statistic result shows that personnel control has no significant impact on budgetary slack with a T-statistic value of 0.432 .

Personnel control involves the Human Resource and Development (HRD) function, especially in recruiting, training, and promoting the best employee to ensure the company is run by the best people (Kleine and Weißenberger, 2014). In this study, the statistic result showed that personnel control does not affect managers' tendency to conduct slack. In some cases, HRD function cannot carry out their best practices due to political reasons or nepotism within the company. Therefore, it is hard to ensure whether companies applied good personnel control or not. Some companies with good corporate governance mechanisms apply good practice during the recruitment, training, and promoting process, as opposed to others. This condition creates mixed, thereby making it difficult to acquire sufficient evidence to prove that personnel control has an impact on budgetary slack.

\section{Conclusion}

In conclusion, the research showed that only organizationa commitment has an impact on budgetary slack among the utilized variables. Therefore, by considering the unique characteristics of Indonesian government enterprises, different results are likely to be obtained. Furthermore, it is recommended to expand this research to private companies or other countries to compare the result and acquire sufficient evidence to enable management to benefit from the informal system.

\section{Acknowledgments}

The authors are grateful to the Universitas Jenderal Achmad Yani for funding this research.

\section{References}

[1] Amran, N. and Auzair, M. S. (2013) 'Incentive Compensation, Organizational Commitment and Managerial Performance in Zakat Institutions', Terengganu International Finance and Economics Journal, 3(2), pp. 50-58.

[2] Anthony, R. and Govindarajan, V. (2006) Management Control System. 12th edn. McGraw-Hill Europe.

[3] Ashmeade, J. A., Mccambridge, G. and Sullivan, J. (2017) 'Ethical Concerns of Budgetary Slack Creation', Journal of Accounting, Ethics \& Public Policy, 18(3), pp. 401-417.

[4] De Baerdemaeker, J., \& Bruggeman, W. (2015). The impact of participation in strategic planning on managers' creation of budgetary slack: The mediating role of autonomous motivation and affective organisational commitment. Management Accounting Research, 29, 1-12. doi:10.1016/j.mar.2015.06.002

[5] Bakar, N. R. binti A. and Amiruddin, R. (2014) 'Impact of Organisational Factors on Budgetary Slack', in E-proceedings of the Conference on Management and Muamalah (CoMM 2014), pp. 978-983.

[6] Belkaoui, A. (1989) Behavioral Accounting: The Research and Practical Issues. Greenwood Press, Inc.

[7] Blay, A., Douthit, J. and Fulmer, B. (2019) 'Why don't people lie? Negative affect intensity and preferences for honesty in budgetary reporting', Management Accounting Research. Elsevier, 42(May 2018), pp. 56-65. doi: 10.1016/j.mar.2018.05.001.

[8] Chong, V. K., \& Ferdiansah, I. (2011). The effect of trust-insuperior and truthfulness on budgetary slack: An experimental investigation. Advances in Management Accounting, 55-73. doi:10.1108/s1474-7871(2011)0000019009.

[9] Church, B. K., Hannan, R. L., \& Kuang, X. (Jason). (2012). Shared interest and honesty in budget reporting. Accounting, Organizations and Society, 37(3), 155-167. doi:10.1016/j.aos.2012.01.002

[10] Delemark, B. and Listherby, C. A. (2013) Budget processes and national culture - putting Hofstede to the test divisions of a Swedish multinational company. Stockholm School of Economics.

[11] Dunk, A. S. (1993) 'The Effect Relation of Budget Between Emphasis the Budgetary Slack and Information Asymmetry on Participation and Slack', The Accounting Review, 68(2), pp. 400-410.

[12] Ekanayake, S. (2004) 'Agency theory, national culture and management control systems', Journal of American Academy of Business, Cambridge, 4(1/2), pp. 49-54. Available at: http://directory.ung.ac.id/bei/Situ/123/EKANAYEKE 04.pdf.

[13] Gago-Rodríguez, S., \& Naranjo-Gil, D. (2016). Effects of trust and distrust on effort and budgetary slack: an experiment. Management Decision, 54(8), 1908-1928. doi:10.1108/md-102015-0480

[14] Ghozali, I. (2014) Structural Equation Modeling Metode Alternatif dengan Partial Least Squares (PLS). Badan Penerbit Universitas Diponegoro.

[15] Gilabert, M., Gago, S. and Naranjo-gil, D. (2012) 'The Relationship between Trust and Budgetary Slack: an Empirical Study', in CEUR Workshop Proceedings.

[16] Hair, J. F., Risher, J. J., Sarstedt, M., \& Ringle, C. M. (2019). When to use and how to report the results of PLS-SEM. European Business Review, 31(1), 2-24. doi:10.1108/ebr-112018-0203.

[17] Hair, J. F. J. et al. (2018) Multivariate Data Analysis. 8th edn. Hampshire: Cengage Learning. doi: 10.1002/9781119409137.ch4.

[18] Harvey, M. E. (2015). The Effect Of Employee Ethical Ideology On Organizational Budget Slack: An Empirical Examination And Practical Discussion. Journal of Business \& Economics Research (JBER), 13(1), 83. doi:10.19030/jber.v13i1.9084

[19] Islami, I. N., \& Nahartyo, E. (2019). DO LEADERSHIP STYLES MODERATE THE RELATIONSHIP OF ORGANIZATIONAL 


\section{GENERAL MANAGEMENT}

COMMITMENT AND BUDGETARY SLACK? AN EXPERIMENTAL APPROACH. Journal of Indonesian Economy and Business, 34(2), 150. doi:10.22146/jieb.32285

[20] Ismanto, H. et al. (2020) 'The impact of risk and financial knowledge, business culture and financial practice on sme performance', Quality - Access to Success, 21(179), pp. 3-9.

[21] Johansson, T., \& Wennblom, G. (2017). In female supervisors male subordinates trust!? An experiment on supervisor and subordinate gender and the perceptions of tight control. Journal of Management Control, 28(3), 321-345. doi:10.1007/s00187017-0248-7

[22] Kahar, S. H. A., Rohman, A., \& Chariri, A. (2016). Participative Budgeting, Budgetary Slack And Job Satisfaction In The Public Sector. Journal of Applied Business Research (JABR), 32(6), 1663 - 1674. doi:10.19030/jabr.v32i6.9814

[23] Klein, H. J. (2012). Commitment in Organizations. doi:10.4324/9780203882122

[24] Kleine, C., \& Weißenberger, B. E. (2013). Leadership impact on organizational commitment: the mediating role of management control systems choice. Journal of Management Control, 24(3), 241-266. doi:10.1007/s00187-013-0181-3

[25] Kyj, L., \& Parker, R. J. (2008). Antecedents of Budget Participation: Leadership Style, Information Asymmetry, and Evaluative Use of Budget. Abacus, 44(4), 423-442. doi:10.1111/j.1467-6281.2008.00270.x

[26] Lestari, D. I. (2020). Do Culture Prevent Slack in Your Budget? The International Journal of Business \& Management, 8(2). 1925, doi:10.24940/theijbm/2020/v8/i2/bm2002-007

[27] Jensen, M. C., \& Meckling, W. H. (1976). Theory of the firm: Managerial behavior, agency costs and ownership structure. Journal of Financial Economics, 3(4), 305-360. doi:10.1016/0304-405x(76)90026-x

[28] Muafi et al. (2017) 'Human capital in Islamic Bank and its effect on the improvement of healthy organization and employee performance', International Journal for Quality Research, 11(4), pp. 849-868. doi: 10.18421/IJQR11.04-08.

[29] Muda, I., Limanto, C. and Erlina (2020) 'An examination of audit delay: Testing several factors of banking issuers as implement global reporting initiative (gri) general disclosures section reporting practice', Journal of Management Systems, 21(178), pp. 114-121.
[30] Nouri, H. and Parker, R. J. (1996) 'The Effect of Organizational

[31] Commitment on the Relation Between Budgetary Participation and Budgetary Slack', Behavioral Research in Accounting, 8, pp. 74-90.

[32] Putra, P. Y. P., Albab, F. N. U., \& Swara, C. C. A. (2019). Reflections on Individual Personal Values in the Budgetary Slack Phenomenontitle>. The Indonesian Journal of Accounting Research, 22(1). doi:10.33312/ijar.433

[33] Reichers, A. E. (1985). A Review and Reconceptualization of Organizational Commitment. Academy of Management Review, 10(3), 465-476. doi:10.5465/amr.1985.4278960

[34] Suhartini, D., Riadi, E. and Sari, R. P. (2015) 'Budgetary Slack and Managerial Performance Models: Gender Perspective', European Journal of Bussiness Management, 7(29), pp. 43-60.

[35] Suhartini, D., Sari, R. P., \& Riadi, E. (2019). Konsekuensi Budgetary Slack: Perspektif Gender. Journal of Accounting Science, 3(1), 37. doi:10.21070/jas.v3i1.2454

[36] Ueno, S., \& Sekaran, U. (1992). The Influence of Culture on Budget Control Practices in the USA and Japan: An Empirical Study. Journal of International Business Studies, 23(4), 659674. doi:10.1057/palgrave.jibs.8490282

[37] Ueno, S. and Wu, F. H. (1993) 'The Comparative Influence of Culture on Budget Control Practices in the United States and Japan', The International Journal of Accounting, 1(28), pp. 211248.

[38] Wibowo, D. E. (2011) 'Peran Ganda Perempuan dan Kesetaraan Gender', Muwazah, 3(1), pp. 356-364.

[39] Yang, M.-L., Wang, A. M.-L., \& Cheng, K.-C. (2009). The impact of quality of IS information and budget slack on innovation performance. Technovation, 29(8), 527-536. doi:10.1016/j.technovation.2009.01.004

[40] Yuhertiana, I. (2011) 'A Gender Perspective of Budgetary Slack in East Java Local Government', International Research Journal of Finance and Economics, (78).

[41] Yukl, G. (1989). Managerial Leadership: A Review of Theory and Research. Journal of Management, 15(2), 251-289. doi:10.1177/014920638901500207.

[42] Zuhdi, S. (2019). MEMBINCANG PERAN GANDA PEREMPUAN DALAM MASYARAKAT INDUSTRI. Jurnal Jurisprudence, $\quad 8(2), \quad 81-86$. doi:10.23917/jurisprudence.v8i2.7327 